\title{
Correction
}

\section{Correction to: Evaluation of adhesion and erosion/corrosion resistance of nano-composite and nano-multilayer thin films in molten aluminum alloy}

\author{
F. Fazlalipour ${ }^{1}$ (D) M. Naghashnejad ${ }^{2} \cdot$ M. Niki Nushari ${ }^{1}$
}

(c) Springer Nature Switzerland AG 2019

\section{Correction to: SN Applied Sciences (2019) 1:1308 https://doi.org/10.1007/s42452-019-1299-1}

There was a typo in the second author's name in the initial online publication. The original article has been corrected.
Publisher's Note Springer Nature remains neutral with regard to jurisdictional claims in published maps and institutional affiliations.

The original article can be found online at https://doi.org/10.1007/s42452-019-1299-1.

$\triangle$ F. Fazlalipour, f.fazlali@gmail.com; M. Naghashnejad, mhmdnn@ou.edu; M. Niki Nushari, malahat.niki@gmail.com|R\&D Department of Iran Radiator Co. Ltd, Rasht 4165956581, Iran. ${ }^{2}$ School of Aerospace and Mechanical Engineering, University of Oklahoma, Norman, OK 73019 , USA. 